\title{
Multi-Criteria Decision Analysis for an Abandoned Quarry in the Evros Region (NE Greece)
}

\author{
Sapfo Tsolaki-Fiaka ${ }^{1}$, George D. Bathrellos ${ }^{1,2, * \mathbb{C}}$ and Hariklia D. Skilodimou ${ }^{2}$ \\ 1 School of Science and Technology, Hellenic Open University, Parodos Aristotelous 18, \\ ZC 26335 Patra, Greece; std75751@eap.gr or sapfotsolaki@gmail.com \\ 2 Department of Geography and Climatology, Faculty of Geology and Geoenvironment, \\ National and Kapodistrian University of Athens, University Campus, Zografou, \\ ZC 15784 Athens, Greece; hskilodimou@geol.uoa.gr \\ * Correspondence: gbathrellos@geol.uoa.gr; Tel.: +30-210-727-4882
}

Received: 2 March 2018; Accepted: 6 April 2018; Published: 10 April 2018 updates

\begin{abstract}
The purpose of this study is to identify the impacts of abandoned quarries and to examine scenarios for their restoration. Two quarries were selected as case studies, which are located in the Evros Region (NE Greece). Initially, the current state of the abandoned quarries was recorded and evaluated, including slopes, landscape, land use, as well as cultural elements. Four alterative scenarios for the exploitation of each quarry were proposed, taking into account the specifics of each site. Financial, environmental, and socioeconomic criteria were then used to evaluate these scenarios. The PROMETHEE method is a multi-criteria decision analysis approach and was applied to rank the alterative scenarios. The results show that the "do nothing" scenario is the worst solution for both quarries. In the quarry at Asvestades, the restoration of the area by returning the land to pre-quarry use with the shaping of the slopes and planting is considered the best solution. On the other hand, in the quarry Mikro Derio two scenarios are proposed; one provides restoring the site to its pre-quarry land use and the other is the restoration of the quarry combined with the creation of a wildlife observatory and places for alternative forms of tourism.
\end{abstract}

Keywords: environmental impact; quarry development; geomorphological characteristics; PROMETHEE method; alterative scenarios

\section{Introduction}

On a global scale, the combined forces of urbanization and rapidly-expanding industry have increased the stress on the natural environment and has resulted in morphological changes in landforms, repeated natural disasters, fragmentation of natural habitats, and degradation of the soil, and surface and ground waters by a wide range of chemical contaminants [1-9]. The continuous and rapid progress of urbanization around the world and the consequent need for mineral sources has largely destroyed many formerly natural ecosystems and left behind many abandoned mines [10]. Mineral extraction, specifically quarrying and open-cast mining is, and will remain, of great economic importance for Europe. Today, there are approximately 7200 quarries cover 250,000 ha in Northwest Europe [11,12]. After extraction, the original landform is permanently altered and the original vegetation cover is destroyed. The visual impact of the quarries may extend over large areas as noticeable scars of high formation and color contrast, reducing the aesthetic appeal of the landscape and deteriorating the scenic quality of the area [13].

Abandoned mining sites are currently a major area of concern as they have consequences for the environmental, economic, and social sectors in traditional rural areas. High restoration costs and a 
lack of involvement of local authorities hamper the implementation of a solution to the environmental degradation [14].

After the end of the quarrying, the land can be reused through restoration. Restoration involves returning the land to its original use, while rehabilitation seeks returning the land to some degree of its former state $[15,16]$. Restoration or rehabilitation of abandoned quarries poses interesting challenges for engineers and environmental scientists. Redeveloping abandoned quarries is not merely about the simple task of re-greening the quarry, but involves a project of creating an ideal place for people with its own ecological, cultural, and leisurely traits by setting up a sustainable landscape design [17].

Studying different types of opencast mines allows the breakdown and understanding of the existence of common features in all mines. The main feature is environmental degradation and, typically, radical change in the landform compared to the previous situation [13]. In many cases the original vegetation cover is destroyed from quarrying activities [18].

The mechanisms of the restoration of quarries according to each country's bureaucracy require the collection of considerable amounts of data for an objective impact assessment. Various studies dealing with models for calculating impact assessments and proposals for the restoration of quarry areas have been released from time to time. Castilla-Gómez et al. propose a methodology to establish an environmental analysis, focusing on the evolution of environmental impacts over time. Since their applied model includes a typical mining operation layout together with adaptive parameters, it is general enough to apply to different mine project designs [19]. Tang et al. suggest three categories of planning function for pit rehabilitation based on the natural condition, the economic and social environment, and land use planning [20]. Prach and Hobbs argued about the value of natural succession instead of technical reclamation in terms of environmental conservation [21].

Milgrom considers that abandoned quarries that are located in conservation areas should be rehabilitated as open spaces [22]. Neri and Sánchez suggest a procedure to evaluate mine rehabilitation practices during the operational phase of a quarry [23].

The type of vegetation to be used for the rehabilitation of the quarry is a concern for many scientists. Novák et al. have studied basalt quarries and discovered that the succession assemblages are not randomly drawn from the vegetation of the wider study area, but depend on the species pool within a close distance [24]. Meira-Neto et al. pointed out that resilience against sudden changes in the environment is a very desirable trait in plants used for ecosystem restoration [25]. Zhang et al. developed and categorized quarry ecosystem recovery indicators based on the core capabilities of the society for ecological restoration [26].

Tropek et al. argue that post-mining management, topography and habitat heterogeneity are the most significant for the conservation value of both plant and invertebrate communities, whereas the surrounding landscape had no effect on the communities [27]. Boscutti et al. consider that both vegetation layer changes and plant traits can be used in achieving effective limestone quarry reclamation [28].

Generally, the proposal for the restoration of quarries is a complicated environmental and socio-economic problem. Selection and evaluation of multiple criteria are involved in this problem. In this context, multi-criteria decision analysis methods can be applied. These methods are decision support tools for dealing with complex decision constellations where environmental, technological, economical, ecological, and social aspects have to be covered [2,29-31], The PROMETHEE (Preference Ranking Organization Method for Enrichment Evaluations) technique is one of the most recent multi-criteria decision analysis methods. It is an outranking approach for a finite set of alternative actions to be ranked and selected among criteria, which are often conflicting [32,33].

The aim of this study is to identify the impacts of abandoned quarries and to examine scenarios for their restoration. The PROMETHEE method was applied to evaluate the scenarios. Additionally, the impacts of the proposed scenarios were assessed. For this purpose two abandoned quarries in NE Greece were selected and used as case studies. 


\section{Study Area}

The study area is in the region of Evros. It is located in Northeastern Greece (Figure 1a) and shares the international boundaries with Bulgaria to the north and Turkey to the east. In this area, there are many of abandoned quarries.

The subject of study in this work are two abandoned aggregate quarries in the Evros Region; one in the Asvestades area and the other of Mikro Derio. They are located in a hilly area and their geological structure consists of limestone. The climate type of the broader area is Mediterranean, although it is affected by continental conditions.

The Asvestades quarry is located in a zone that combines a forest area and cultivated areas. In this quarry a consortium of companies mined limestone to produce aggregates to meet local needs and, in particular, the construction needs of local roads.

The quarry of Mikro Derio is an aggregate quarry located within a forested area. It is located away from urban regions, and has been abandoned since 1985 .

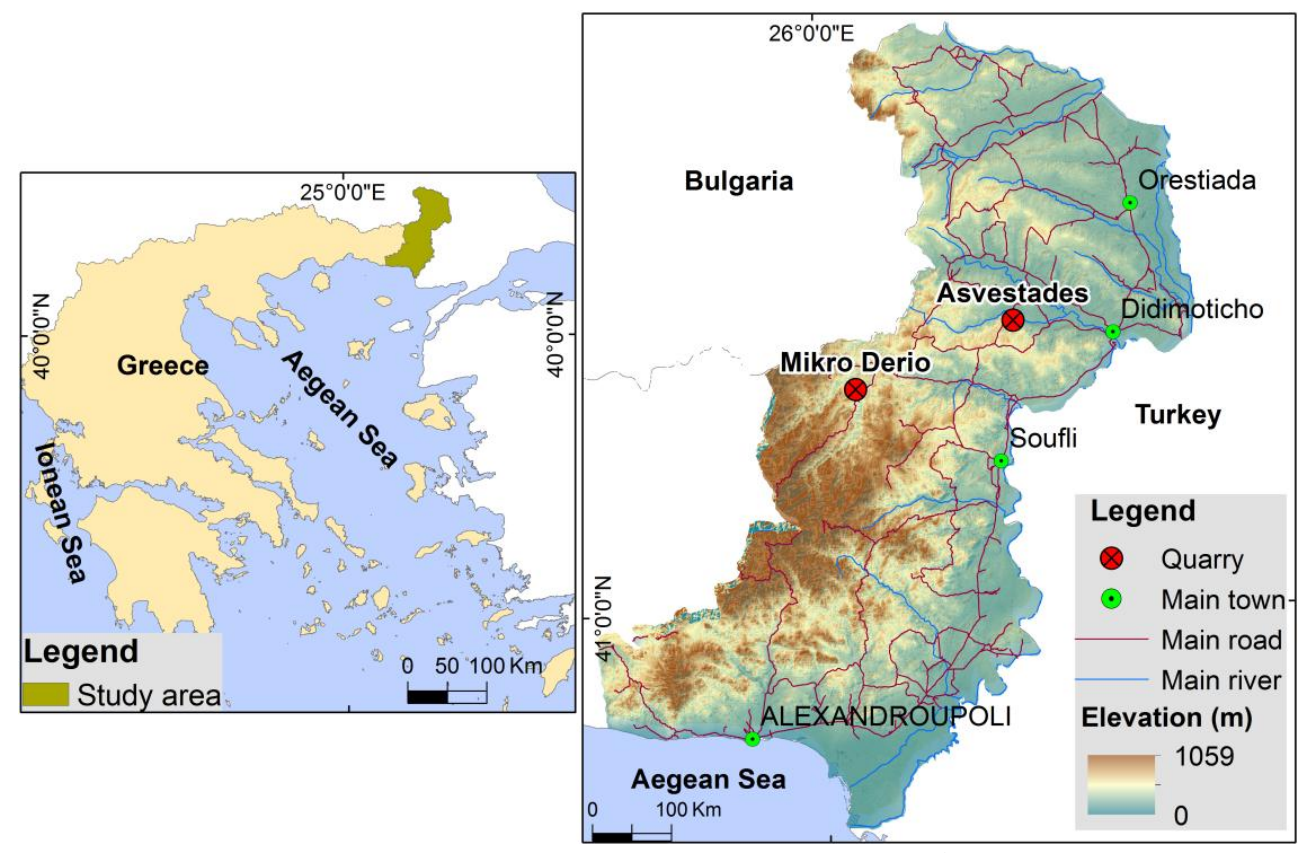

(a)

(b)

Figure 1. (a) Location map of the region of Evros; and (b) the location map of the quarries of Asvestades and Mikro Derio with elevations, main towns, main drainage network, and main road network.

\section{Materials and Methods}

\subsection{Data Sources}

In each abandoned quarry's topographical surveying was carried out, illustrating the landform and geomorphological elements of the quarries (such as slopes and gullies), the abandoned existing infrastructure and road access [34].

Field work was carried out to record the impact on the quarry sites. Data collection included the description of the site, slopes, location, and land use. The effects on the environment from the operation and abandonment of the quarries were also recorded. The fieldwork observations were used to investigate exploitation scenarios for these quarries. The recorded observations concerning impacts were categorized in two groups, environmental and socio-economic. The environmental impact assessment group includes recorded data relating to the alteration of the landscape, changes in flora and fauna of the region, erosion following the abandonment of the quarry, and data in general on the environmental degradation due to quarrying activities. In the socio-economic impact assessment 
group elements related to the safety of the residents were recorded, such as the existence or not of fenced areas and slope stability. Illegal activities occurred in the area, such as the extraction of aggregates and logging. In addition, land encroachments were observed at the edges of the quarry mining areas, as well as the use of the quarry roads by the locals.

\subsection{Scenarios for Quarry Expoitation}

The suggested scenarios to exploit each quarry are listed below. The same scenarios were applied to both quarries. In this way, the results were compared and the scenarios were evaluated [34]. Since both quarries are located within Natura 2000 areas, each scenario described below was designed to protect the species of the region and restore the quarry in such a way as to have similar characteristics with its environment. The applied scenarios were:

- A1: Do Nothing.

- A2: Restoration of the quarry area by shaping slopes and planting.

- A3: Restoration of the quarry area by shaping slopes, redevelopment relief, and planting to exploit the area for logging.

- A4: Restoration of the quarry area by shaping slopes, redevelopment relief, and planting with the operation of facilities for alternative forms of recreation/tourism.

\subsection{PROMETHEE Method and Input Data}

Each scenario has multiple recipients with potentially conflicting interests regarding the usefulness, degree of acceptance, and significance of impact. For this purpose it was considered mandatory to use a multi-criteria method in this research. The applied method is the PROMETHEE method, which is a multi-criteria decision analysis as developed by Brans et al. [35]. It is also quite a simple ranking method. A number of successful applications have been treated by the PROMETHEE methodology in various fields, such as industrial location, water resources, medicine, chemistry, health care, and tourism. The success of the methodology is basically due to its mathematical properties and to its particular friendliness of use [36,37]. This method is based on the principles of outranking relation theory and permits effective action selection with respect to options (PROMETHEE I) and ranking (PROMETHEE II). It is based on a comparison pair per pair of possible decisions along each criterion. The input for the PROMETHEE method is a set of potential alternatives (actions). They are evaluated according to different criteria, which have to be maximized or minimized. Determination of the weights is an important step in most multi-criteria methods. The method normalizes the criteria weights so that their sum is equal to $1.0(100 \%)$. PROMETHEE II assumes that the decision-maker is able to weigh the criteria appropriately, at least when the number of criteria is not too large [32,37].

In the present study the alternative set for the exploitation of the two quarries and the criteria set were defined. In this way, it was possible to evaluate the proposals. The used software to evaluate the proposals is Visual Promethee 1.4 Academic Edition [38].

Scenarios A1, A2, A3, and A4 are the alternative set of the method and were evaluated by using specific criteria. These were chosen based on the impact of each alterative scenario on the environment, and on the society and economy of the area. For this reason the judgment criteria set of the applied method were grouped into three categories as follows:

(a) financial criteria: construction, operation and maintenance costs,

(b) environmental criteria: environmentally-protected areas, pollution, land encroachments, impacts on flora and fauna, landscape aesthetics, noise,

(c) socioeconomic criteria: safety of residents, land use changes in the area, economic redevelopment for the locals (employment growth, promoting local products etc.), tourism, temporary disturbance during construction.

Possible decisions took into account the importance of the criteria weight. However, the decision-makers may be individuals, such as engineers, environmental managers, landowners, public 
organizations, ministries, local authorities, or project financiers. They may also have conflicting opinions or preferences on the alternative scenarios. Different possible decisions (solutions) were carried out using different weights for each criterion, to reconcile the different opinions on the problem of the exploitation of the two quarries. Five categories of possible decisions were created, in order to include all criteria for each quarry, which are described below:

1. The $33 \%$ decision: the used weight of all criteria was 0.33 (33\%): in this category, an attempt was made to include the possible opinion of decision-makers such as public organizations, ministries, and local authorities.

2. Neutral decision: all criteria for each category have the same weight.

3. Environmental decision: since the two quarries are located in Natura areas, the weight for environmental criteria was $0.5(50 \%)$, for socioeconomic criteria $w=0.25(25 \%)$, and for financial criteria $w=0.25(25 \%)$. This possible decision expresses the opinions of decision-makers such as environmental managers.

4. Socioeconomic decision: the weight for socioeconomic criteria was $0.5(50 \%)$, for environmental criteria $w=0.4(40 \%)$, and for financial criteria $w=0.1(10 \%)$. This category expresses the opinions of individuals such as locals, landowners, and engineers.

5. Financial decision: the weighting factor for the criteria of costs was $0.5(50 \%)$, and it expresses the opinions or preferences of financiers.

The evaluation of alternative scenarios was applied for the five categories of possible decisions for both quarries.

\section{Results and Discussion}

\subsection{Quarry at Asvestades}

The extraction of the aggregate materials was primarily executed with explosives with no planned quarrying process. Two mining faces are visible in the quarry, which are illustrated in the topographical surveying that follows (Figure 2). Throughout the quarry, the absence of benches is evident, resulting in an extraction area consisting of a vertical face of 18-20 m (Figures 2 and 3). The remaining area includes two mining cavities up to $25 \mathrm{~m}$ deep (Figures 2 and 4). Natura habitats have been identified in the research area and are located within the protected Natura areas under the code GR1110011, "Erythropotamos valley: Asvestades, Koufobouno, Vrysika" [39].

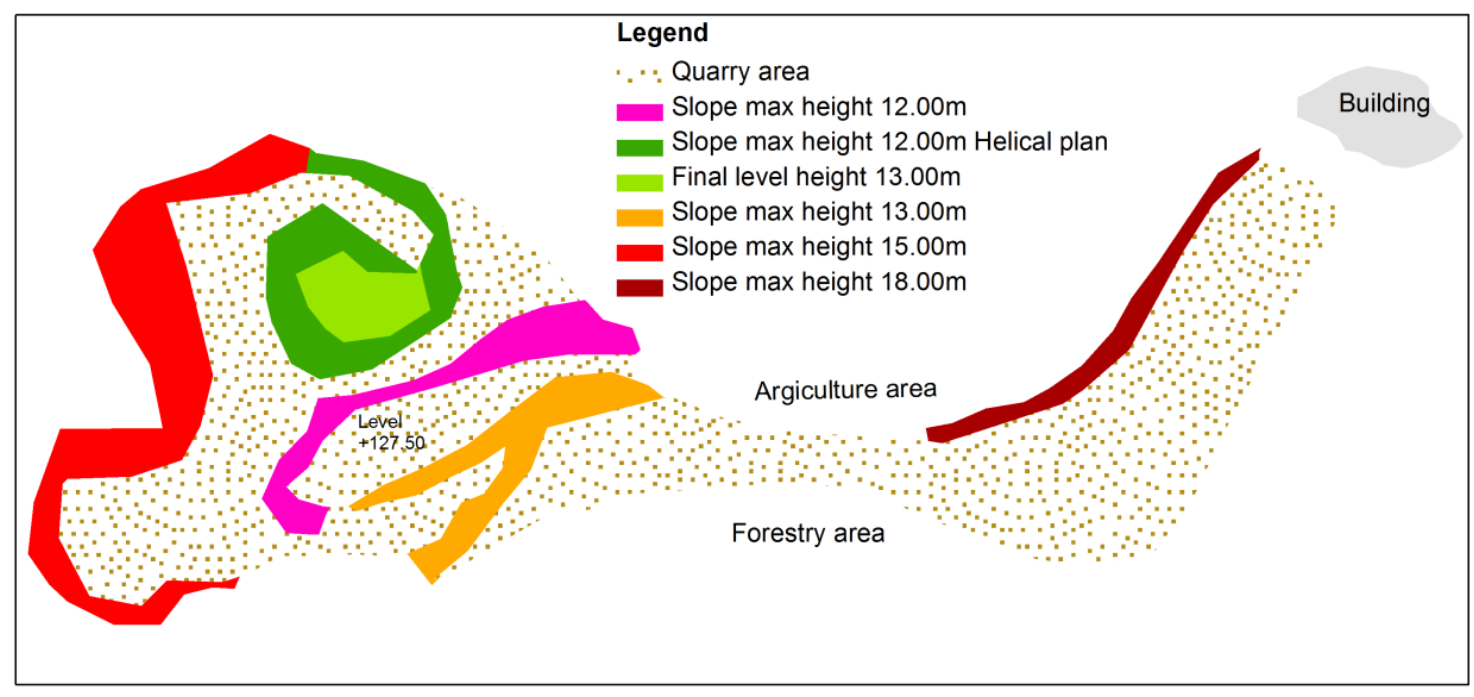

Figure 2. Topographical survey of the quarry site in the Asvestades area, scale 1:2000. 


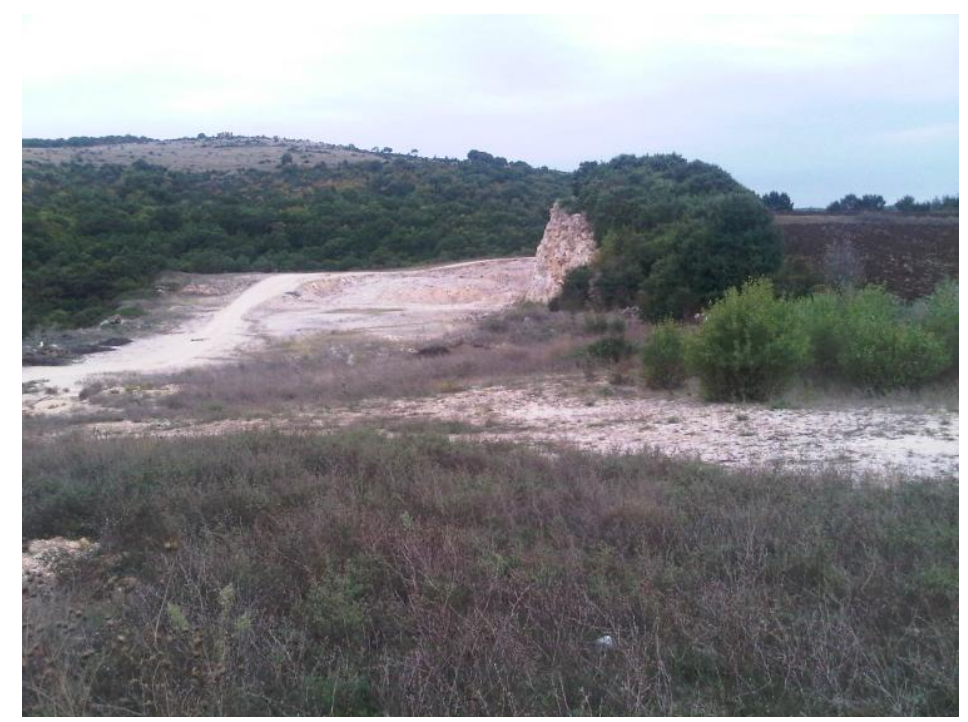

Figure 3. Area of the quarry, vertical face of 18-20 m next to existing agricultural land.

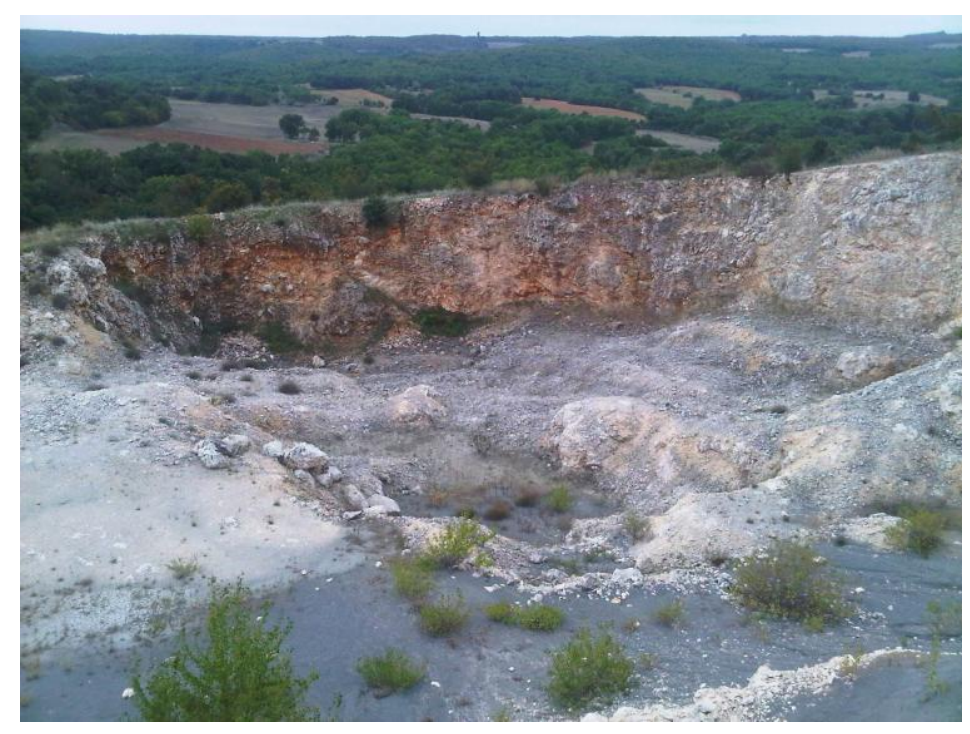

Figure 4. Area of the quarry with a prominent area of vegetation regeneration.

\subsection{Quarry at Mikro Derio}

The quarry covers a relatively minor area in size consisting of the main level extraction, which was created with the use of explosives (Figures 5 and 6), and a second lower level of mining, which was created using mechanical equipment. The quarry is located within protected Natura areas, more specifically, the one with the segment code GR111010, "Mountain Evros-Derio Valley", which has been described as Special Protection Area (SPA) [39].

The vegetation consists mainly of oak and beech forests with small clusters of pine trees (Figure 7). Woodland made up of scattered oaks covers a large part of this area, used by locals for non-intensive grazing animals. The vegetation is vital for the feeding of the unique Black Vulture species, resident in Greece. 


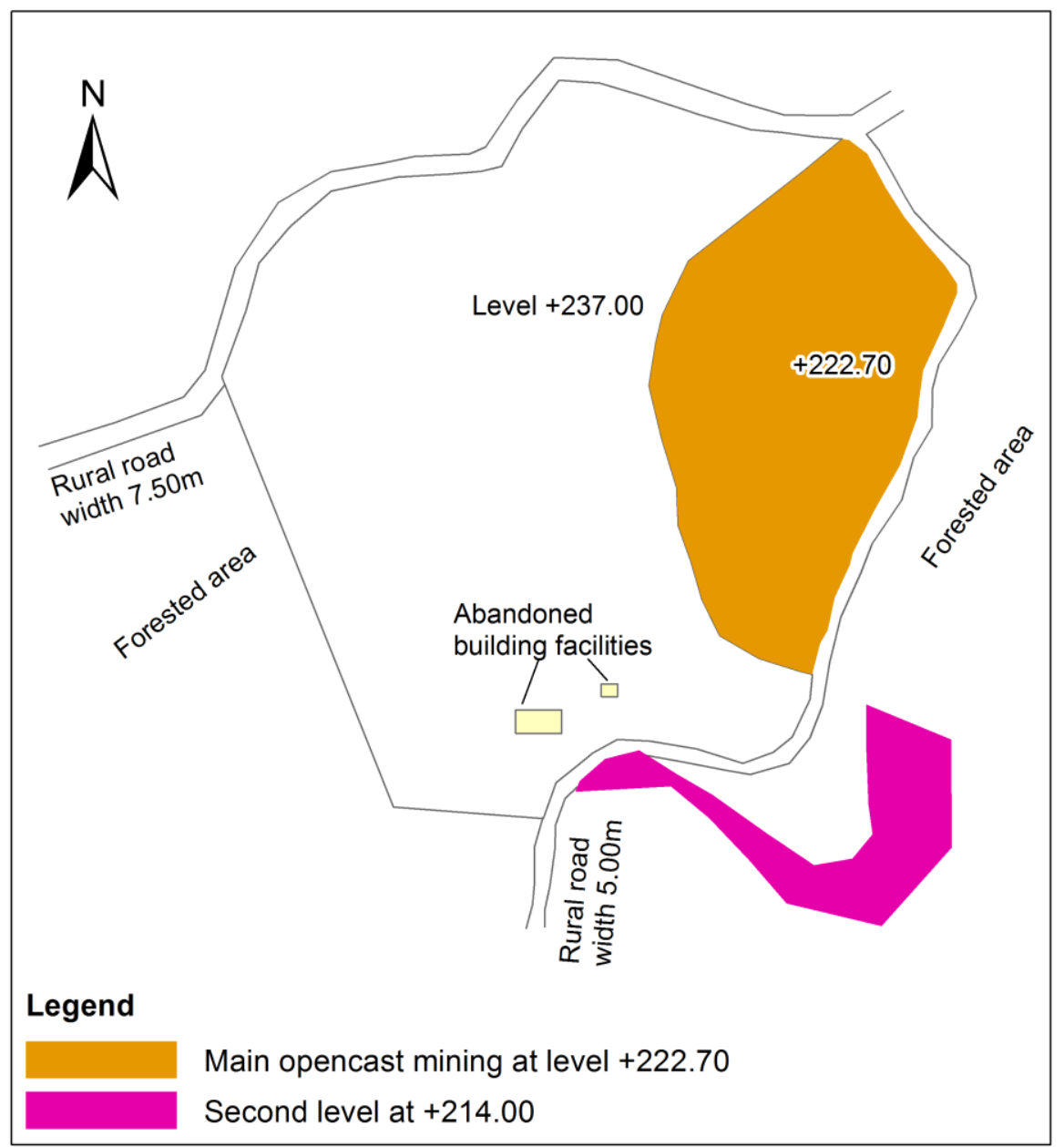

Figure 5. Topographical survey of the quarry at Mikro Derio, scale 1:2000.

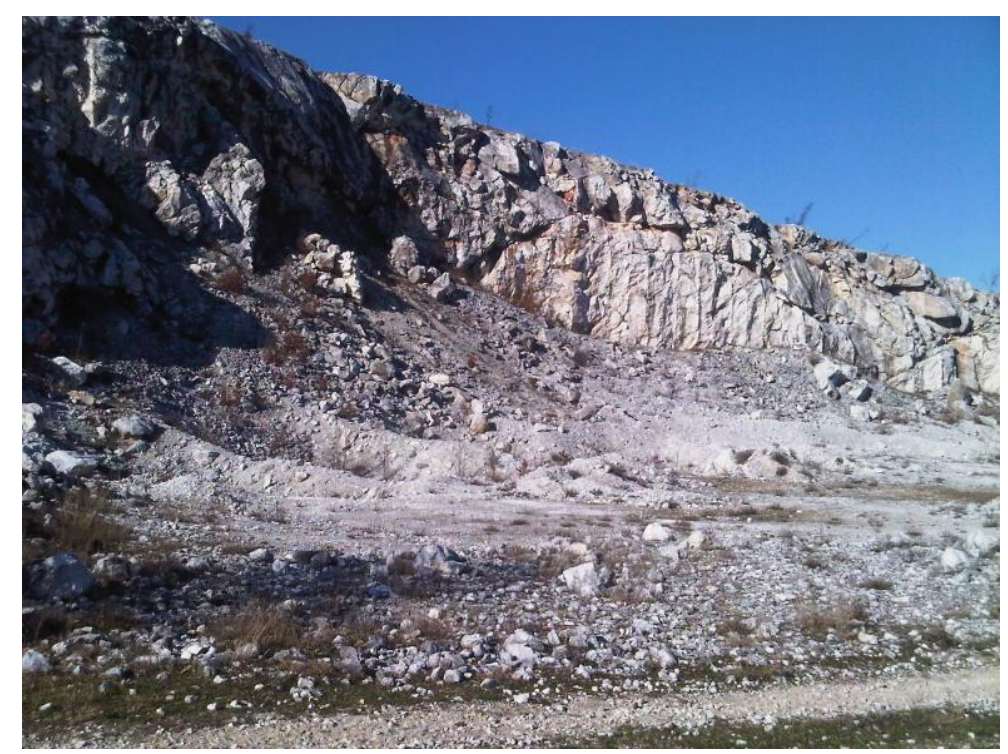

Figure 6. Vertical face of the quarry at Mikro Derio. 


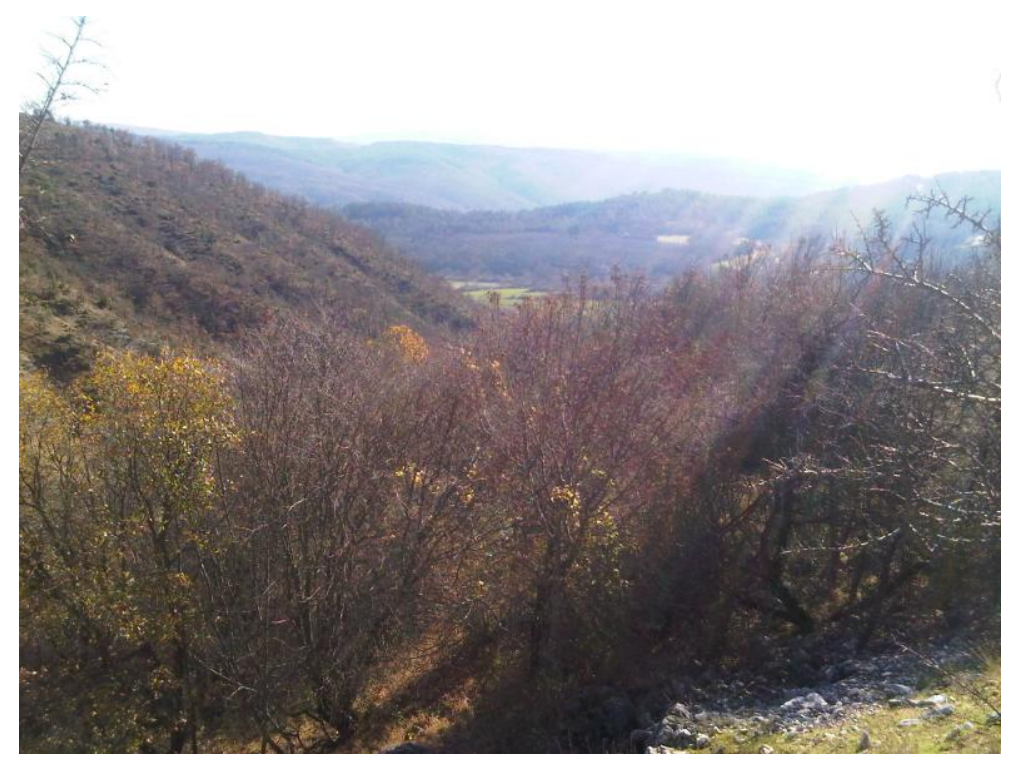

Figure 7. Forest area in front of the Mikro Derio quarry.

\subsection{Impact of the Abandoned Quarries}

Since many of the effects are similar in both quarries, and in order to avoid repetition, a summary table (Table 1) provides the main impacts of the abandoned quarries, which were noted during the site visits.

Table 1. Pivot table impact presentation of the study of the abandoned quarries.

\begin{tabular}{ccc}
\hline Impact Description & Asvestades & Mikro Derio \\
\hline Visual pollution & - & $\sqrt{ }$ \\
Landscape aesthetics & $\sqrt{ }$ & $\sqrt{ }$ \\
Alteration of the landscape & $\sqrt{ }$ & - \\
Flooding and erosion & $\sqrt{ }$ & $\sqrt{ }$ \\
Loss of flora and fauna & $\sqrt{ }$ & - \\
Illegal dumping & $\sqrt{ }$ & $\sqrt{ }$ \\
Illegal logging & - & $\sqrt{ }$ \\
Illegal mining and aggregate removal & $\sqrt{ }$ & $\sqrt{ }$ \\
Risk of slope instability & $\sqrt{ }$ & $\sqrt{ }$ \\
Land use changes (forest, agricultural) & $\sqrt{ }$ & $\sqrt{ }$ \\
Land Value reduction & $\sqrt{ }$ &
\end{tabular}

Concerning the environmental impacts of both quarries, the aesthetic alteration of the landscape and the changes in geomorphologic characteristics of the area are very intense due to their former intensive exploitation. The deposition of quarry waste within the quarry area also caused the shrinkage or/and the disappearance of vegetation. The mining operations and the deposition quarry waste caused changes in the surface runoff of rainwater and soil erosion.

In terms of socio-economic impacts, both abandoned quarries are affected by the illegal extraction of aggregates. The complete lack of security in both quarries has resulted in the illegal dumping of urban waste within the quarry area (Asvestades quarry). Moreover, the lack of quarry fencing endangers the lives of inhabitants or visitors because of the possible failure of the existing slopes.

\subsection{Proposed Quarry Exploitation}

The proposal to exploit the abandoned quarry of Asvestades includes four alternative scenarios, which are: 
- A1: Do nothing. The quarry remains abandoned.

- A2: Restoration of the quarry by returning the land to the pre-quarry use. This scenario includes a series of actions to be taken, such as landfill, shaping slopes, planting, and fencing of the site.

- A3: Restoration of the quarry by creating forestry land. The economic exploitation of the site through logging is planned. This scenario provides returning the landscape to some degree of its former state and includes actions such as shaping slopes, redevelopment of the landscape and planting with rapid-growth saplings for logging.

- A4: Restoration of the quarry by creating places for people to enjoy and relax, and places for tourism and cultural events. Similarly to scenario A3, it is expected that restoring the land to some degree of its former state and the restoration plan involves actions such as shaping slopes, redevelopment relief, and planting with the creation of an observatory, leisure area, parking for visitors, and areas for cultural events. The proposed type of restoration for the quarry, according to the current scenario, is illustrated in Figure 8.

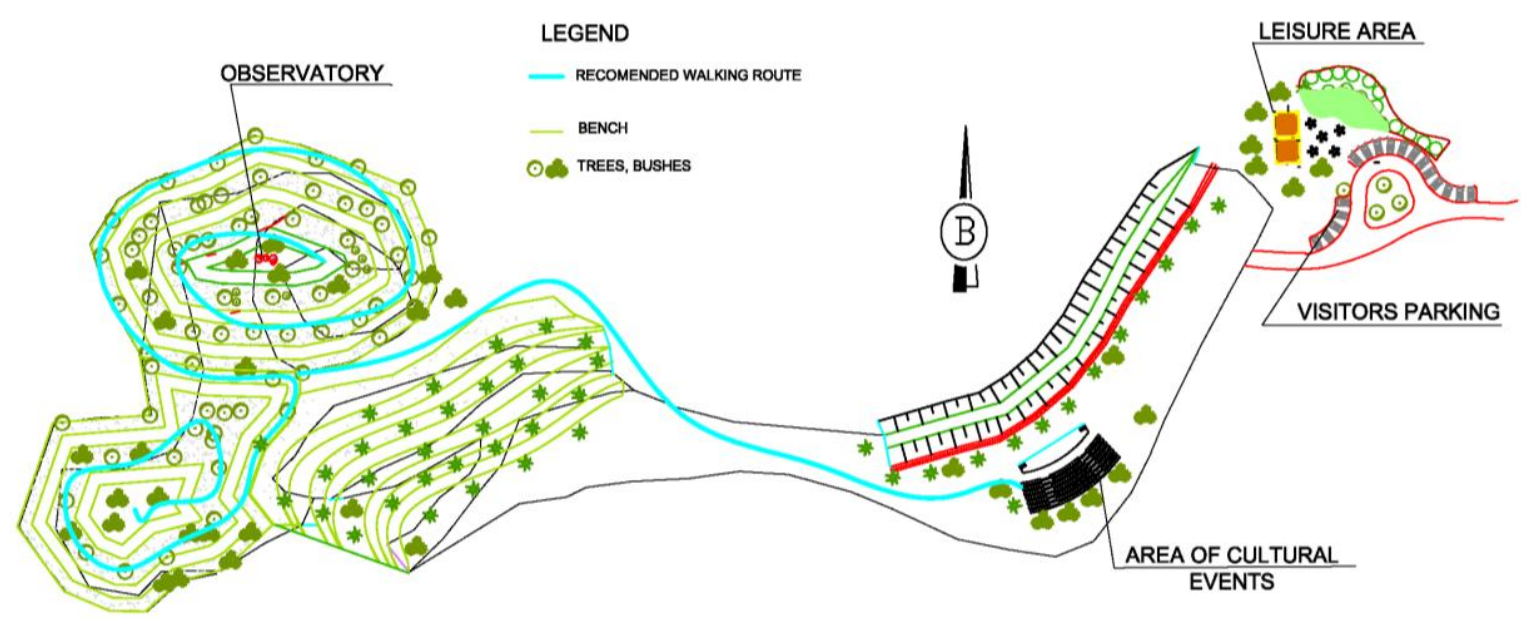

Figure 8. Restoration proposals for the quarry in Asvestades according to the alternative scenario A4, scale 1:2000.

The procedure for implementing the PROMETHEE method starts with the determination of alternatives and criteria. It continues with the evaluation of alternatives according to different criteria, calculating positive and negative outranking flows for each alternative and partial ranking by PROMETHEE I. The procedure ends with the calculation of the net outranking flow for each alternative and complete ranking by PROMETHEE II [32,40].

Figure 9 is a graphical representation of partial ranking by PROMETHEE I. According to Mareschal, the leftmost vertical bar corresponds to the positive flow values (Phi+), the rightmost to the negative flow values (Phi-), and the central vertical bar to the net flow values (Phi) [41]. For each alternative scenario a line is drawn between its Phi+ and Phi- values. When an alternative scenario is preferred to another, its line lies on top of the other's line. When two lines cross each other, the corresponding scenarios are incomparable. Figure 10 also shows the complete ranking by PROMETHEE II. The vertical bar corresponds to the net flow values. Positive scale values are green, while negative values are red. Alternatives are positioned according to their net flow values. Moreover, in Figure 11 the results of the evaluation of alternative scenarios for the five categories of possible decisions were compared. 


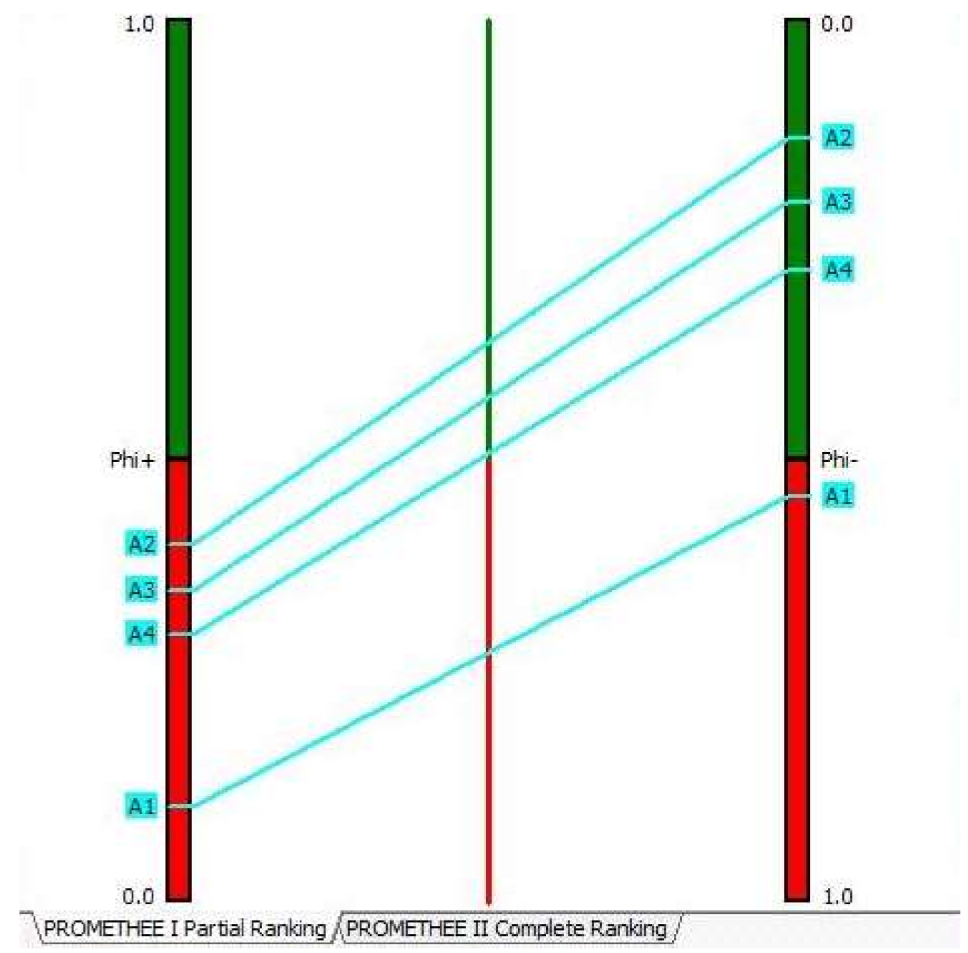

Figure 9. Partial ranking of alternatives based on the PROMETHEE I method, taking into consideration all categories of possible decisions (Asvestades quarry).

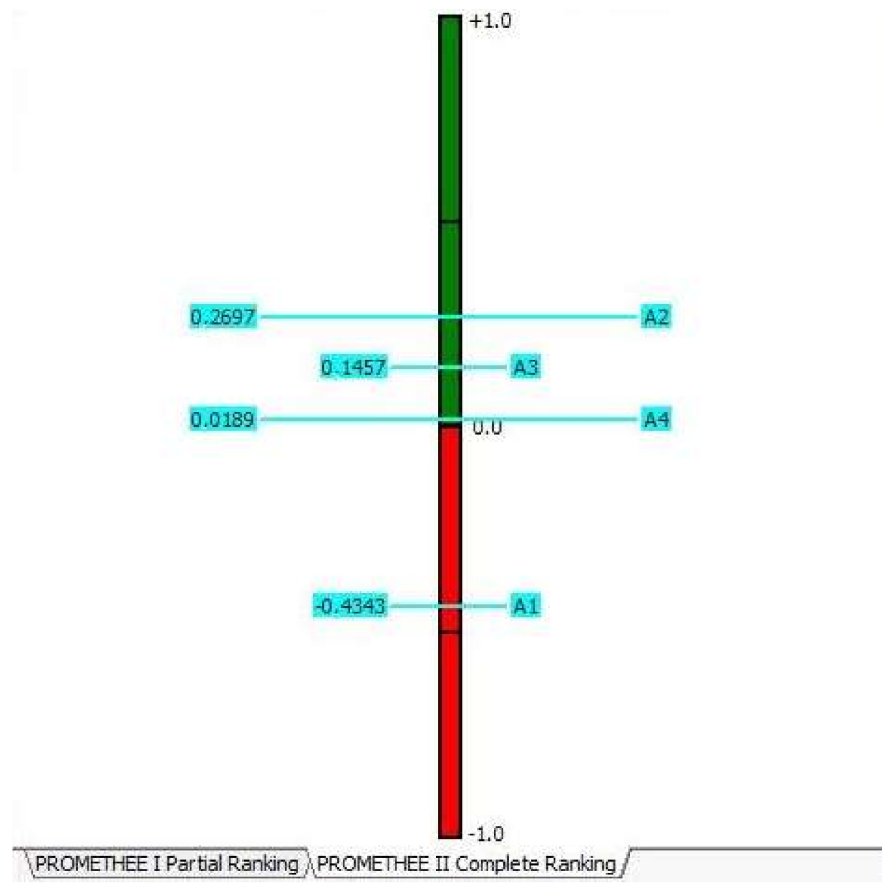

Figure 10. Complete ranking of alternatives based on the PROMETHEE II method, taking into consideration all categories of possible decisions (Asvestades quarry). 


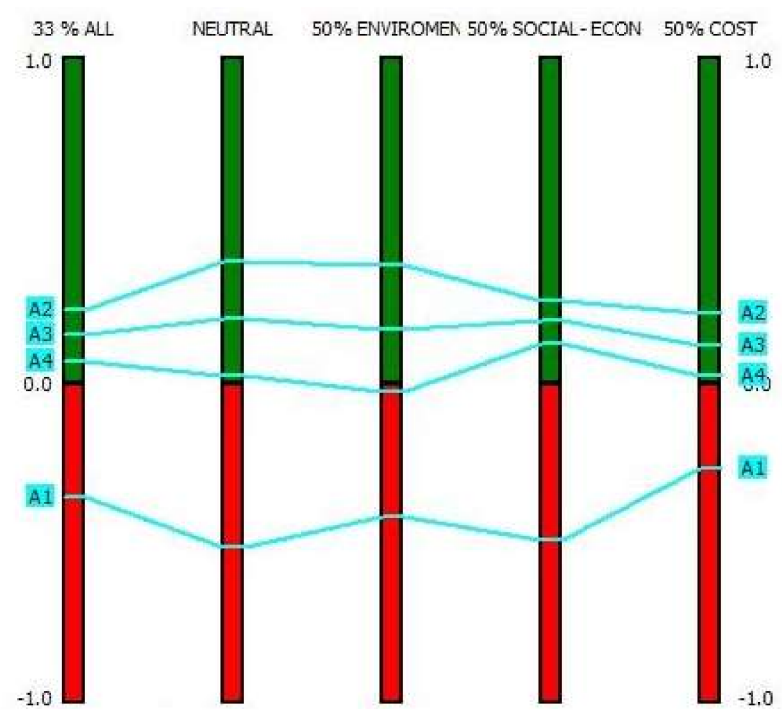

Figure 11. Result comparison of the five possible decisions for the Asvestades quarry.

As it is shown in Figures 9-11, the ranking by the PROMETHEE I and PROMETHEE II methods are:

Scenario A2 > A3 > A4 > A1

The first rank belongs to scenario A2. This means that A2 is the best choice and outranked the other alternative scenarios for the exploitation of the Asvestades quarry regarding the given criteria. The second best option is scenario A3.

On the contrary, scenario A1 is the worst solution for the exploitation of the Asvestades quarry, bearing the worst performance in the criteria, as expected.

Scenario A4, which focuses on restoration with the creation of tourist areas is the second most inappropriate proposal for the quarry at Asvestades. The high financial cost of this type of restoration is the main reason for this result. Moreover, the creation of places for cultural and social activities reduces the positive environmental potential criteria.

Similarly, in the case of the quarry at Asvestades, the exploitation of the Mikro Derio quarry includes four alternative scenarios. The first scenario (A1) is to keep the site of the abandoned quarry as it is. The second scenario (A2) provides restoring the site to its pre-quarry land use. According to the third scenario (A3), the site is restored and planted with rapid-growth saplings in order to exploit it for logging. The fourth scenario (A4), proposes restoration of the quarry in combination with the use of existing buildings by creating a wildlife observatory and places for recreation and alternative forms of tourism (Figure 12).

Figures 13-15 indicate that A2 is the best choice, followed by A4, A3, and A1, respectively. As in the case of Asvestades quarry, scenario A1 is an absolutely inappropriate choice considering the aforementioned criteria. Scenario A3, i.e., proposing the restoration and then the exploitation by logging, is the second most inappropriate proposal. This ranking is attributed to the unfavorable environmental criteria which are created because Mikro Derio is an area with an intense forest character.

Scenario A2 has a higher position than A4 based on the ranking by PROMETHEE II (Figure 14). The two scenarios are marginally incomparable according to the ranking by PROMETHEE I (Figure 13). However, it is particularly interesting to focus on the comparison of the results for the five possible decisions of Figure 15. When greater weight is given to the socio-economic criteria, then scenario A4 is a better choice than A2, since A4 retains a high enough performance with respect to the environmental criteria and it has the best performance with respect to the socioeconomic criteria, such as tourism, financial support of the local society, the increased price of land, etc. 
Consequently, the selection of criteria weights expressing the opinion or preference of the decision-maker greatly influence the outcome. The multi-criteria method is determined by the decision-makers' personal choices in terms of objective criteria, weight of the criteria, and assessing achievement of the objectives.

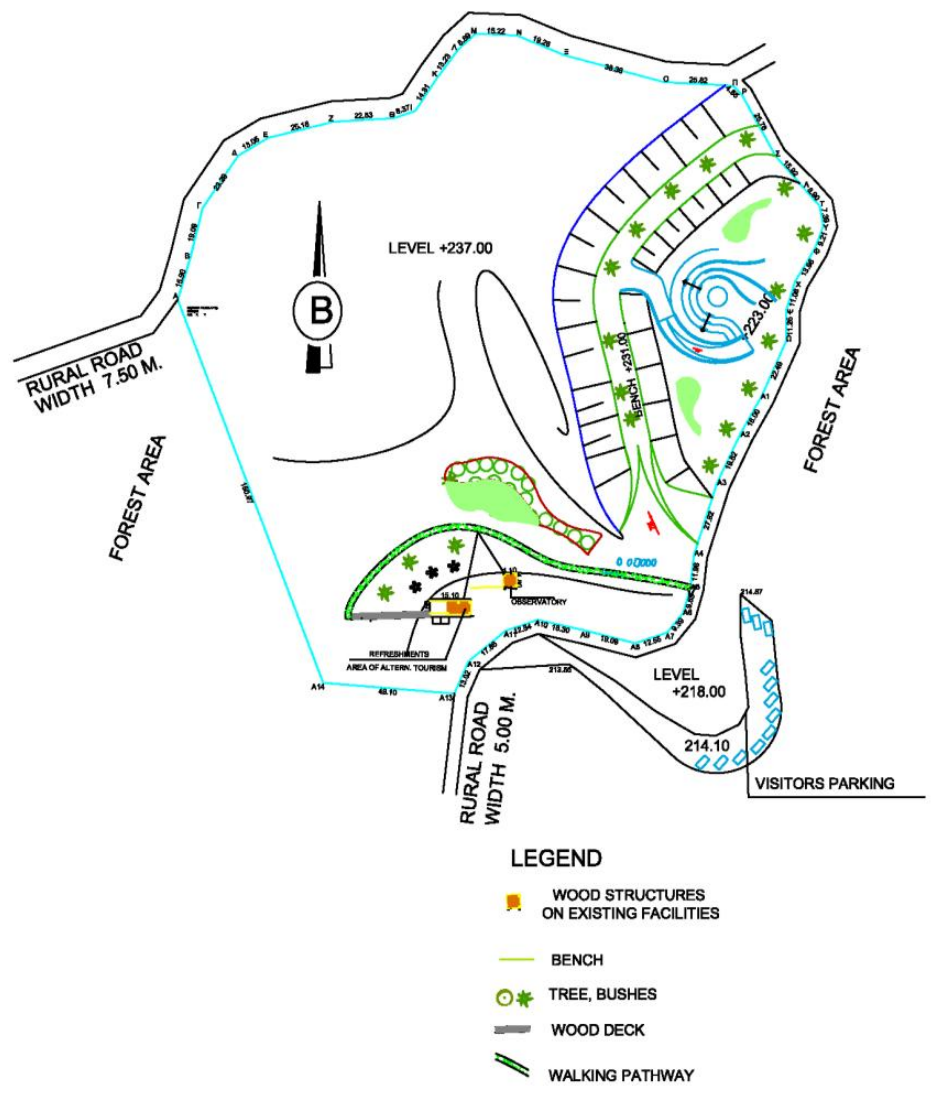

Figure 12. Restoration proposals for the quarry in Mikro Derio according to the alternative scenario A4, scale 1:2000.

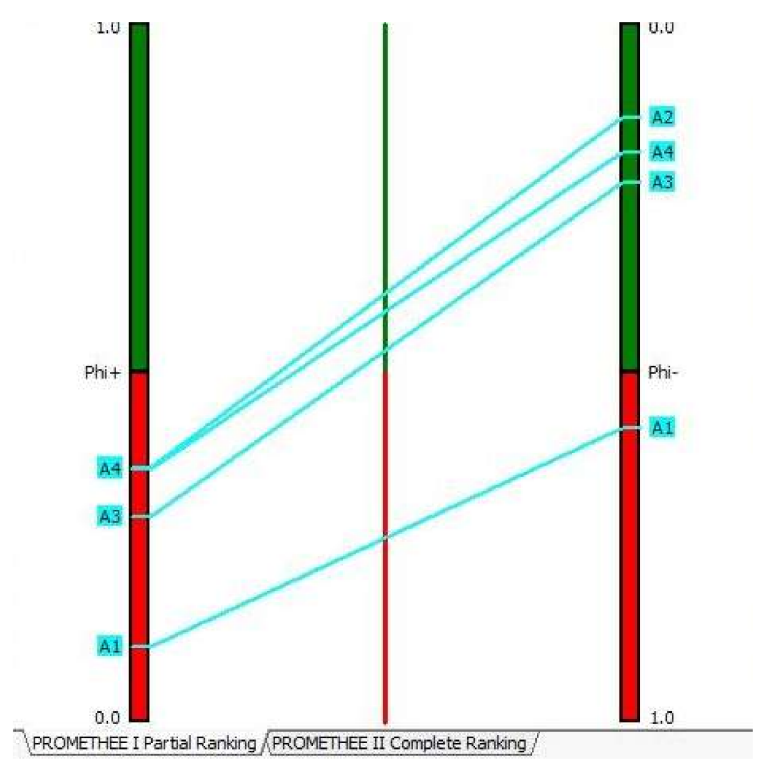

Figure 13. Partial ranking of alternatives based on the PROMETHEE I method, taking into consideration all categories of possible decisions (Mikro Derio quarry). 


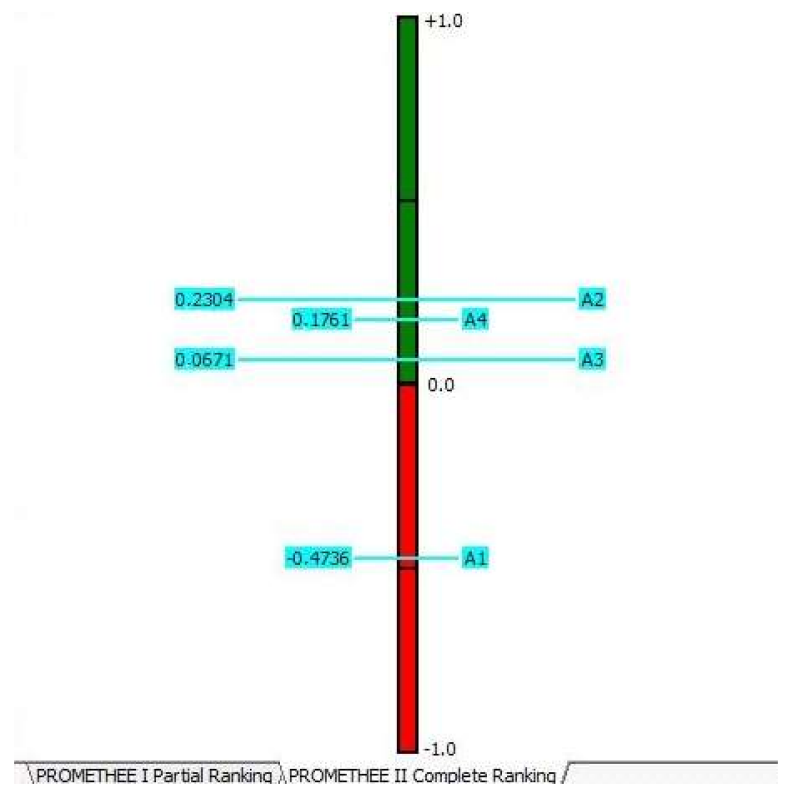

Figure 14. Complete ranking of alternatives based on the ROMETHEE II method, taking into consideration all categories of possible decisions (Mikro Derio quarry).

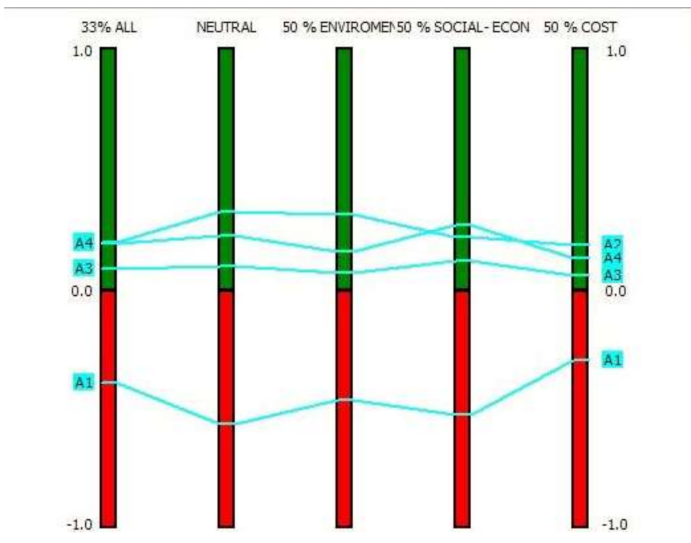

Figure 15. Result comparison of the five possible decisions for the Mikro Derio quarry.

\section{Conclusions}

Two abandoned quarries, the quarry of Asvestades and the quarry of Mikro Derio were assessed for their restoration. The assessment of the environmental impacts of two abandoned quarries, the changes in the geomorphologic characteristics of the area, such as landscape and surface runoff, and the alterations in vegetation cover were recorded. Concerning the socioeconomic impacts, the complete lack of security and fencing of both quarries creates a risk for residents and caused the illegal extraction of aggregates and the illegal deposition of urban waste within the quarry areas.

Four scenarios for the exploitation of each quarry were proposed, taking into account the above-mentioned impacts of each site. They were evaluated by using financial, environmental, and socioeconomic criteria. The problem of the restoration of quarries is multi-dimensional and cannot be resolved with the use of only one criterion, requiring the use of a multi-criteria decision-making methodology. For this reason the PROMETHEE method was applied.

The results prove that the scenario A1, i.e., "do nothing", is an absolutely inappropriate choice for both quarries. In the quarry of Asvestades the results show that the best choice is scenario A2, which 
involves the restoration of the area by returning the land to the pre-quarry use, with the shaping of slopes and planting. On the contrary, in the quarry at Mikro Derio, when in the environmental criteria are given greater weight, the best solution is scenario $\mathrm{A} 2$. When the socioeconomic criteria have the greatest weight, the best selection is scenario A4, which involves restoration of the quarry combined with the creation of a wildlife observatory and places for recreation and alternative forms of tourism.

Acknowledgments: The constructive and thorough reviews of anonymous reviewers are warmly acknowledged. Additionally, we would like to thank Hampik Maroukian for the editing of the English language.

Author Contributions: Sapfo Tsolaki-Fiaka conceived the research; Sapfo Tsolaki-Fiaka and George D. Bathrellos designed the research and the data analysis; Sapfo Tsolaki-Fiaka prepared and analyzed the data; Sapfo Tsolaki-Fiaka completed the field work; Sapfo Tsolaki-Fiaka and Hariklia D. Skilodimou created the figures; and Sapfo Tsolaki-Fiaka, George D. Bathrellos, and Hariklia D. Skilodimou wrote the paper.

Conflicts of Interest: The authors declare no conflict of interest.

\section{References}

1. Bathrellos, G.D.; Skilodimou, H.D.; Kelepertsis, A.; Alexakis, D.; Chrisanthaki, I.; Archonti, D. Environmental research of groundwater in the urban and suburban areas of Attica region, Greece. Environ. Geol. 2008, 56, 11-18. [CrossRef]

2. Bathrellos, G.D.; Skilodimou, H.D.; Maroukian, H. The spatial distribution of Middle and Late Pleistocene Cirques in Greece. Geogr. Ann. A 2014, 96, 323-338. [CrossRef]

3. Bathrellos, G.D.; Skilodimou, H.D.; Chousianitis, K.; Youssef, A.M.; Pradhan, B. Suitability estimation for urban development using multi-hazard assessment map. Sci. Total Environ. 2017, 575, 119-134. [CrossRef] [PubMed]

4. Panagopoulos, G.P.; Bathrellos, G.D.; Skilodimou, H.D.; Martsouka, F.A. Mapping Urban Water Demands Using Multi-Criteria Analysis and GIS. Water Resour. Manag. 2012, 26, 1347-1363. [CrossRef]

5. Papadopoulou-Vrynioti, K.; Bathrellos, G.D.; Skilodimou, H.D.; Kaviris, G.; Makropoulos, K. Karst collapse susceptibility mapping using seismic hazard in a rapid urban growing area. Eng. Geol. 2013, 158, 77-88. [CrossRef]

6. Papadopoulou-Vrynioti, K.; Alexakis, D.; Bathrellos, G.D.; Skilodimou, H.D.; Vryniotis, D.; Vassiliades, E.; Gamvroula, D. Distribution of trace elements in stream sediments of Arta plain (western Hellas): The influence of geomorphological parameters. J. Geochem. Explor. 2013, 134, 17-26. [CrossRef]

7. Papadopoulou-Vrynioti, K.; Alexakis, D.; Bathrellos, G.D.; Skilodimou, H.D.; Vryniotis, D.; Vasiliades, E. Environmental research and evaluation of agricultural soil of the Arta plain, western Hellas. J. Geochem. Explor. 2014, 136, 84-92. [CrossRef]

8. Rozos, D.; Bathrellos, G.D.; Skilodimou, H.D. Comparison of the implementation of Rock Engineering System (RES) and Analytic Hierarchy Process (AHP) methods, based on landslide susceptibility maps, compiled in GIS environment. A case study from the Eastern Achaia County of Peloponnesus, Greece. Environ. Earth Sci. 2011, 63, 49-63. [CrossRef]

9. Rozos, D.; Skilodimou, H.D.; Loupasakis, C.; Bathrellos, G.D. Application of the revised universal soil loss equation model on landslide prevention. An example from N. Euboea (Evia) Island, Greece. Environ. Earth Sci. 2013, 70, 3255-3266. [CrossRef]

10. Wang, J.; Li, Z.; Hu, X.; Wang, J.; Wang, D.; Qin, P. The ecological potential of a stored abandoned quarry ecosystem in Mt. Mufu, Nanjing China. Ecol. Eng. 2011, 37, 833-841. [CrossRef]

11. UEPG (European Aggregates Association). A Sustainable Industry for a Sustainable Europe; Annual Review; UEPG: Brussels, Belgium, 2012; p. 40.

12. Wilker, J.; Rusche, K.; Benning, A.; MacDonald, M.A.; Blaen, P. Applying ecosystem benefit valuation to inform quarry restoration planning. Ecosyst. Serv. 2016, 20, 44-55. [CrossRef]

13. Redondo-Vega, J.M.; Gómez-Villar, A.; Santos-González, J.; González-Gutiérrez, R.B.; Álvarez-Martínez, J. Changes in land use due to mining in the north-western mountains of Spain during the previous 50 years. Catena 2016, 149, 844-856. [CrossRef]

14. Merciu, G.-L.; Merciu, F.-C.; Cercleux, A.-L. The Assessment of Social and Economic Impacts Associated to an Abandoned Mining Site Case study: Ciudanovita (Romania). Procedia Environ. Sci. 2016, 32, 420-430. 
15. Clemente, A.S.; Werner, C.; Máguas, C.; Cabral, M.S.; Martins-Loução, M.A.; Correia, O. Restoration of a limestone quarry: Effect of soil amendments on the establishment of native Mediterranean sclerophyllous shrubs. Restor. Ecol. 2004, 12, 20-28. [CrossRef]

16. SER. International Primer on Ecological Restoration; Society for Ecological Restoration International Science \& Policy Working Group: Washington, DC, USA, 2004; p. 13.

17. Zhu, D.-D.; Song, Y.-S.; Li, L. Study on sustainable landscape design of abandoned quarries: An example: Zhushan ecological park in Xuzhou. Procedia Earth Planet. Sci. 2009, 1, 1107-1113.

18. Mouflis, G.D.; Gitas, I.Z.; Iliadou, S.; Mitri, G.H. Assessment of the visual impact of marble quarry expansion (1984-2000) on the landscape of Thasos island, NE Greece. Landsc. Urban Plan. 2008, 86, 92-102. [CrossRef]

19. Castilla-Gómez, J.; Herrera-Herbert, J. Environmental analysis of mining operations: Dynamic tools for impact assessment. Miner. Eng. 2015, 76, 87-96. [CrossRef]

20. Tang, Y.; Jia, H.; Jiang, Q.; Wang, J. Comprehensive rehabilitation planning of deserted pits and the case study in plain area of Beijing, China. Landsc. Urban Plan. 2011, 99, 123-132. [CrossRef]

21. Prach, K.; Hobbs, R.J. Spontaneous succession versus technical reclamation in the restoration of disturbed sites. Restor. Ecol. 2008, 16, 363-366. [CrossRef]

22. Milgrom, T. Environmental aspects of rehabilitating abandoned quarries: Israel as a case study. Landsc. Urban Plan. 2008, 87, 172-179. [CrossRef]

23. Neri, A.C.; Sánchez, L.E. A procedure to evaluate environmental rehabilitation in limestone quarries. J. Environ. Manag. 2010, 91, 2225-2237. [CrossRef] [PubMed]

24. Novák, J.; Konvička, M. Proximity of valuable habitats affects succession patterns in abandoned quarries. Ecol. Eng. 2005, 26, 113-122. [CrossRef]

25. Meira-Neto, J.A.A.; Clemente, A.; Oliveira, G.; Nunes, A.; Correia, O. Post-fire and post-quarry rehabilitation successions in Mediterranean-like ecosystems: Implications for ecological restoration. Ecol. Eng. 2011, 37, 1132-1139. [CrossRef]

26. Zhang, Q.; Zhang, T.; Liu, X. Index System to Evaluate the Quarries Ecological Restoration. Sustainability 2018, 10, 619. [CrossRef]

27. Tropek, R.; Hejda, M.; Kadlec, T.; Spitzer, L. Local and landscape factors affecting communities of plants and diurnal Lepidoptera in black coal spoil heaps: Implications for restoration management. Ecol. Eng. 2013, 57, 252-260. [CrossRef]

28. Boscutti, F.; Vianello, A.; Bozzato, F.; Casolo, V. Vegetation structure, species life span, and exotic status elucidate plant succession in a limestone quarry reclamation. Restor. Ecol. 2017, 25, 595-604. [CrossRef]

29. Bathrellos, G.D.; Gaki-Papanastassiou, K.; Skilodimou, H.D.; Papanastassiou, D.; Chousianitis, K.G. Potential suitability for urban planning and industry development by using natural hazard maps and geological-geomorphological parameters. Environ. Earth Sci. 2012, 66, 537-548. [CrossRef]

30. Bathrellos, G.D.; Gaki-Papanastassiou, K.; Skilodimou, H.D.; Skianis, G.A.; Chousianitis, K.G. Assessment of rural community and agricultural development using geomorphological-geological factors and GIS in the Trikala prefecture (Central Greece). Stoch. Environ. Res. Risk Assess. 2013, 27, 573-588. [CrossRef]

31. Bathrellos, G.D.; Karymbalis, E.; Skilodimou, H.D.; Gaki-Papanastassiou, K.; Baltas, E.A. Urban flood hazard assessment in the basin of Athens Metropolitan city, Greece. Environ. Earth Sci. 2016, 75, 319. [CrossRef]

32. Behzadian, M.; Kazemzadeh, R.B.; Aghdasi, M.; Albadvi, A. PROMETHEE: A comprehensive literature review of applications and methodologies. Eur. J. Oper. Res. 2010, 200, 198-215. [CrossRef]

33. Brans, J.P.; Mareschal, B. PROMETHEE methods. In Multiple Criteria Decision Analysis: State of the Art Surveys; Figueira, J., Salvatore, G., Ehrgott, M., Eds.; Springer: Berlin, Germany, 2005; pp. 163-195.

34. Tsolaki-Fiaka, S. Recording Abandoned Quarries in the Evros Region, Methods of Exploitation and Impact Assessment. Master's Thesis, Hellenic Open University, Patra, Greece, 2017.

35. Brans, J.P.; Mareschal, B.; Vincke, P. PROMETHEE: A new family of outranking methods in multi-criteria analysis. In Operational Research; Brans, J.P., Ed.; Universite Libre de Bruxelles: Bruxelles, Belgium, 1984; pp. 477-490.

36. Brans, J.P.; Vincke, P.H.; Mareschal, B. How to select and how to rank projects: The PROMETHEE method. Eur. J. Oper. Res. 1986, 24, 228-238. [CrossRef]

37. Macharis, C.; Brans, J.P.; Mareschal, B. The GDSS PROMETHEE procedure-A PROMETHEE-GAIA based procedure for group decision support. J. Decis. Syst. 1998, 7, 283-307. 
38. Mareschal, B. Visual PROMETHEE Academic Edition. Available online: http://www.promethee-gaia.net/ academic-edition.html (accessed on 9 April 2018).

39. Filotis. FILOTIS: Database for the Natural Environment of Greece. Available online: http:/ / filotis.itia.ntua.gr (accessed on 12 November 2016).

40. Goumas, M.; Lygerou, V. An extension of the PROMETHEE method for decision making in fuzzy environment: Ranking of alternative energy exploitation projects. Eur. J. Oper. Res. 2000, 123, 606-613. [CrossRef]

41. Mareschal, B. The PROMETHEE-GAIA FAQ. Using the Visual PROMETHEE Software. Available online: http:/ / www.promethee-gaia.net (accessed on 27 March 2018).

2018 by the authors. Licensee MDPI, Basel, Switzerland. This article is an open access article distributed under the terms and conditions of the Creative Commons Attribution (CC BY) license (http://creativecommons.org/licenses/by/4.0/). 